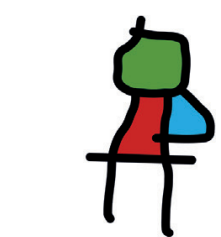

SEICAIP

\section{Allergologia et immunopathologia}

Sociedad Española de Inmunología Clínica, Alergología y Asma Pediátrica

www.all-imm.com

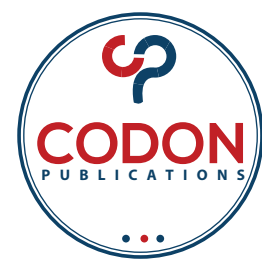

\title{
Oral food challenge in lgE mediated food allergy in eastern Mediterranean children
}

\author{
Hilal Ünsala , Gökçe Özyılmaz Bozat Gb, Melike Ocaka ${ }^{\mathrm{a}}$ Ayșegül Akarsua, \\ Ümit Murat Şahinera, Özge Soyera ${ }^{a}$, Bülent Enis Şekerela*
}

\author{
${ }^{a}$ Department of Pediatric Allergy, Hacettepe University Faculty of Medicine, Ankara, Turkey \\ ${ }^{b}$ Department of Pediatrics, Hacettepe University Faculty of Medicine, Ankara, Turkey
}

Received 13 July 2020; Accepted 1 December 2020

Available online 1 May 2021

\section{KEYWORDS \\ anaphylaxis; \\ children; \\ food allergy; \\ IgE; \\ oral food challenge; \\ positive reaction}

\begin{abstract}
Background: The oral food challenge (OFC) in IgE mediated food allergy causes anxiety both in parents and in patients due to its inherent risks.

Objective: Documentation of the rate, spectrum, and predictors of positive reactions is instructive.

Methods: Children, who underwent OFC between January 1, 2017 and December 31, 2019 were analyzed.

Results: A total of 1361 OFCs in 613 cases were reviewed. Most of them were performed in preschool children ( $\leq 2$ years $50 \%$ ) and $55 \%$ of them had more than one OFC. Mainly considered food groups were cow's milk (31.8\%), hen's egg $(28.5 \%)$, tree nuts $(20 \%)$, legumes $(7 \%)$, seeds $(4.9 \%)$, and wheat $(2.7 \%)$. The overall OFC positivity was $9.6 \%$, whereas $6.7 \%$ with cow's milk, $4.9 \%$ with hen's egg, $16.1 \%$ with tree nuts, $21.6 \%$ with wheat, and $32.8 \%$ with seeds. The severity scoring revealed grade I (24.4\%), II (45.8\%), and III (29.7\%) reactions. Fifty (38\%) cases required epinephrine and four cases required hospitalization. OFCs with sesame seeds (odds ratio [OR]: 7.747, [confidence interval ( $\mathrm{Cl})$ 95\%: 4.03-14.90]), wheat (OR: 3.80, [Cl: 1.64-8.84]), and tree nuts (OR: 2.78 , [Cl: $1.83-4.23]$ ) predicted a positive OFC while a concomitant asthma (OR: 3.61 [Cl: 1.27-10.28]) was more likely to elicit anaphylaxis.

Conclusion: In OFC practice, priority is given to basic nutritional sources and the most frequent food allergens, where preschool children with multiple sensitizations are the primary subjects. Increased risks of positive reactions with sesame, tree nut, and wheat and increased risk of anaphylaxis with concomitant asthma should be considered while performing OFC.

(C) 2021 Codon Publications. Published by Codon Publications.
\end{abstract}

*Corresponding author: Bülent Enis Sekerel, MD, Professor of Pediatrics, Hacettepe University Faculty of Medicine, Department of Pediatric Allergy, 06100 Ankara Turkey. Email address: b_sekerel@yahoo.com 


\section{Introduction}

In recent years, the prevalence of IgE-mediated food allergies (FA) has steadily increased and emerged as a significant health problem. ${ }^{1}$ Furthermore, more than half of these patients have multiple FAs. ${ }^{2,3}$ Though skin prick tests (SPTs) and specific IgE are routinely used for clinical work-ups, oral food challenge (OFC) is still the gold standard diagnostic test. ${ }^{4,5}$ In clinical practice, OFCs are usually performed to diagnose/confirm FA or to determine the tolerance or resolution of an allergy. ${ }^{6,7}$ OFCs carry inherent risks as positive OFC symptoms can range from mild to potentially life threatening. ${ }^{8}$ Though the severity of reactions can be predicted by SPTs or food-specific IgE levels, it is not the case for the most. ${ }^{9,10}$ Thus, experienced professionals are needed to ensure that symptoms are recognized quickly and treatment initiated promptly to optimize outcomes. ${ }^{11}$ Documentation of OFC-related experiences like the rate, spectrum, and predictors of positive reactions is informative and instructive if we are to improve the outcomes of health services. In this study, we retrospectively analyzed the OFCs we have performed, to examine whether inputs and outcomes varied based on the characteristics of OFC predictors.

\section{Materials and Methods}

\section{Study design and subjects}

All OFCs evaluating IgE mediated FAs/sensitivities performed between January 1, 2017 and December 31, 2019 in Hacettepe University Pediatric Allergy Division, which is a referral center for the entire country of Turkey, were reviewed retrospectively for the clinical outcomes, laboratory data, demographic characteristics, presence of other allergies, comorbidities, and for the type of treatment if the challenge was positive.

\section{Oral food challenge}

OFCs were performed based on the clinical decision of the attending physician, along with clinical history and results of allergy testing. In summary, OFCs were conducted according to the national guideline that was in consonant with the PRACTALL consensus by applying 3, 10, 30, $100,300,1000,3000 \mathrm{mg}$ food protein at $15-30$ min intervals according to the amount of protein contained in the food. ${ }^{12}$ Challenges were terminated as soon as objective symptoms were observed. ${ }^{13}$ Treatment for positive reactions was performed according to the type and severity of the symptoms. Age-appropriate doses of antihistamine for cutaneous symptoms, inhaled salbutamol for lower respiratory symptoms, and systemic steroid were used. If the patient met the criteria for anaphylaxis, intramuscular epinephrine was administered..$^{14}$ When there was a reaction, patients were observed at least for $4 \mathrm{~h}$.

\section{Diagnostic procedures}

The diagnosis of IgE mediated food sensitization was defined as a positive SPT ( $3 \mathrm{~mm}$ or more above the negative control) and/or positive specific IgE ( $\geq 0.35 \mathrm{kU} / \mathrm{L})$. Allergen extracts (ALK ${ }^{\circledR}$, Horsholm, Denmark) were applied on the volar surface of the forearm or back along with negative and positive controls. Mean wheal diameter was measured after 15 min by calculating mean value of the longest diameter and the diameter perpendicular to it. Allergen-specific IgE levels were measured by the Immuno-CAP method in the sera of the patients (Phadia, Uppsala, Sweden) within 2 months before OFC.

\section{Ethics}

OFC was not performed in patients with uncontrolled asthma, severe atopic dermatitis and allergic rhinitis, and with ongoing disease. Patients taking medication including antihistamines, neuroleptics, oral steroid, aspirin and other NSAID's, ACE-inhibitors, and beta-blockers were challenged after the completion of their medications or excluded depending on their situation. ${ }^{15}$ OFC was performed if the parents and patient (if $>7$ year of age) had given informed consent. The local ethics committee (GO-20/515) of the Hacettepe University Faculty of Medicine approved this retrospective study.

\section{Statistical analysis}

Statistical analysis was performed using IBM SPSS Statistics for Windows v.22.0 (IBM Corp., Armonk, NY, USA). Descriptive analysis was used to characterize the patients. Pearson's $x 2$ test or Fisher's exact test was used for between-group comparisons. Values are shown as the median and interquartile range (IQR) for data not normally distributed. The Mann-Whitney U test or Kruskal-Wallis test was used to compare values. Univariate and multivariate analyses were performed to predict persistence. Factors that were significant based on univariate regression analysis $(p<0.2)$ were then included as covariates in multiple regression analysis. The odds ratio (OR) with relevant $95 \%$ confidence interval $(\mathrm{Cl})$ was calculated via univariate and multivariate analyses. All statistical tests were two-sided, and the level of statistical significance was set at $p<0.05$.

\section{Results}

\section{Study population}

Between January 1, 2017 and December 31, 2019, 1361 OFCs were performed in 613 children. Out of this number, $66.2 \%$ were males. In addition, $50.18 \%$ (683/1361) of OFCs were performed in children $\leq 2$ years $(14.3 \% \leq 1$ year, $90 \%$ $\leq 6$ years). Remarkably, 262 (42.8\%) patients had single food-group sensitization/allergy and 351 (57.2\%) had multiple ones $(\geq 2)$. From 613 children, 276 (45\%) had single OFC during the study period, $170(27.73 \%)$ had two, 72 received three $(11.75 \%), 95(15.50 \%)$ had four or greater OFCs. Most of the children had comorbid atopic disease, that is, atopic dermatitis $(58.3 \%)$, asthma $(14.6 \%)$, and allergic rhinitis (1.9\%) (Table 1).

The median age during OFC was 2 years (IQR 1.2-3.3) in the study population. When the ages of the patients during 
Table 1 The characteristics of the study group and its subgroups

\begin{tabular}{|c|c|c|c|c|c|c|}
\hline & $\begin{array}{l}\text { Whole Group } \\
\text { (n:1361) }\end{array}$ & $\begin{array}{c}\text { OFC (+) Group } \\
(\mathrm{n}: 131)\end{array}$ & $\begin{array}{c}\text { OFC (-) Group } \\
(\mathrm{n}: 1230)\end{array}$ & $P$ value & $\begin{array}{l}\text { OFC( } \leq 2 \text { years) } \\
\text { Group (n:683) }\end{array}$ & $\begin{array}{c}\text { OFC }(2-18 \text { years }) \\
\text { Group }(\mathrm{n}: 678)\end{array}$ \\
\hline Age $^{*}$ & $2(1.2-3.3)$ & $2.03(1.2-3.86)$ & $2(1.15-3.31)$ & NS & $1.16(0.95-1.53)$ & $3.35(2.53-5.27)$ \\
\hline Gender-male, n (\%) & $901(66.2)$ & $94(71.7)$ & $807(65.6)$ & NS & $433(63.4)$ & $468(69)$ \\
\hline History of asthma, n (\%) & $199(14.6)$ & $21(16)$ & $178(14.5)$ & NS & $35(5.1)$ & $164(24.2)$ \\
\hline History of ICS usage $n(\%)$ & $154(10.9)$ & $16(12.2)$ & $138(11.2)$ & NS & $20(2.9)$ & $134(19.8)$ \\
\hline $\begin{array}{l}\text { History of atopic } \\
\text { dermatitis, n (\%) }\end{array}$ & $793(58.3)$ & $76(58)$ & $717(58.3)$ & NS & $422(61.8)$ & $371(54.7)$ \\
\hline $\begin{array}{l}\text { History of allergic } \\
\text { rhinitis, } n(\%)\end{array}$ & $26(1.9)$ & $2(1.5)$ & $24(2)$ & NS & $3(0.4)$ & $23(3.4)$ \\
\hline \multicolumn{7}{|l|}{ Laboratory findigs } \\
\hline $\operatorname{slgE}(k U / L)^{*}$ & $1.15(0.31-3.42)$ & $1.95(0.7-5.71)$ & $1.06(0.27-3.16)$ & $<0.001$ & $0.63(0.14-1.65)$ & $2.08(0.64-5.39)$ \\
\hline Total IgE (kU/L)* & $82.6(27.6-293.5)$ & $98.9(34.5-534)$ & $80.1(27.6-278.5)$ & 0.027 & $37.2(14.5-117)$ & $185(69-584)$ \\
\hline SPT (mm wheal)* & $2(0-5)$ & $4(0-6)$ & $2(0-5)$ & $<0.001$ & $0(0-4)$ & $4(0-6.5)$ \\
\hline Eosinophil (n)* & $300(200-600)$ & $300(200-500)$ & $300(200-600)$ & 0.703 & $300(200-525)$ & $300(200-600)$ \\
\hline Eosinophil (\%)* & $3.5(2.2-5.7)$ & $3.6(2.1-5.8)$ & $3.5(2.2-5.6)$ & 0.891 & $3.4(2.2-5.4)$ & $3.6(2.2-6)$ \\
\hline Basophil(n)* & $100(0-100)$ & $100(0-100)$ & $100(0-100)$ & 0.499 & $100(0-100)$ & $0(0-100)$ \\
\hline Basophil (\%)* & $0.5(0.4-0.7)$ & $0.55(0.4-0.8)$ & $0.5(0.4-0.7)$ & 0.528 & $0.5(0.4-0.7)$ & $0.6(0.4-0.8)$ \\
\hline
\end{tabular}

*median, IQR (interquartile range)

different food challenges were analyzed, it was 2.03 (1.213.56) for cow's milk, 1.80 (1.07-2.95) for hen's egg, 2.19 (1.42-3.57) for tree nuts, $2.36(1.13-4.40)$ for wheat, 1.55 (1.06-3.01) for sesame, 1.16 (0.84-2.1) for poppy seeds, and 1.94 (1.13-3.36) for legumes. Moreover, the proportion of children $\leq 2$ years was $49.2 \%$ (213/433) for cow's milk, 54.6\% $(212 / 388)$ for hen's egg, $44.3 \%(121 / 273)$ for tree nuts, 48.6 $\%(18 / 37)$ for wheat, $56.9 \%(29 / 51)$ for sesame, $75 \%(9 / 12)$ for poppy seeds, and 52.5\% (52/99) for legumes (Table 2).

\section{OFCs and outcomes}

Most of the OFCs were performed with cow's milk (31.8\%), followed by hen's egg (28.5\%), tree nut (20\%), legume (7\%), seeds $(4.9 \%)$, and wheat $(2.7 \%)$ (Table 2$)$. When all OFCs are considered, the positive reaction rate was $9.6 \%(131 / 1361)$, with $6.7 \%$ (29/433) coming from cow's milk, 4.9\% (19/388) from hen's egg, $16.1 \%(44 / 273)$ from tree nuts, $21.6 \%(8 / 37)$ from wheat, $35.2 \%(18 / 51)$ from sesame, $33.3 \%$ (4/12) from poppy seeds, and $8 \%(8 / 99)$ from legumes. Within the tree nut group, the positive reaction rate was $26.2 \%(11 / 42)$ for cashews, $23.9 \%(16 / 67)$ for walnut, $17.8 \%$ (8/45) for hazelnut, 9.1\% (5/55) for pistachio, and 6.3\% (4/64) for almond. Positive reaction rate was the highest in bean $(22.2 \%)$ within the legume group and sesame (35.2\%) among the seed group. The positive reaction rates among the foods are summarized in Table 2.

When positive OFC related symptoms were considered, most of them were cutaneous (81.7\%; urticaria, angioedema, flushing, pruritus, itching), respiratory (35.9\%; sneezing, rhinorrhea wheezing, cough, and dyspnea), and gastrointestinal (26.7\%; vomiting, nausea, abdominal colic) (Figure 1). The severity scoring of positive OFCs revealed grade I (24.4\%), II (45.8\%), and III (29.7\%) reactions. Among positive OFCs, 50 (38\%) cases received intramuscular epinephrine: 39 patients $(29.7 \%)$ received one dose, eight patients received $(6.1 \%)$ two, two patients received $(1.5 \%)$ three, and one patient received $(0.76 \%)$ four doses. $68.7 \%$ $(90 / 131)$ of the patients were treated with antihistamine, $45.8 \%(60 / 131)$ with systemic corticosteroids, $20.6 \%(27 / 131)$ with inhaled salbutamol, and $3 \%$ (4/131) with nebulized adrenalin. Only four $(0.3 \%)$ required hospitalization, of whom three were in intensive care unit. Among the hospitalized patients, one was from those who were challenged with the hen's egg while the other three in intensive care unit came from the group challenged with tree nuts. No fatality was observed.

\section{Predictors of reactivity}

There was no difference between those who passed or failed the OFC with regard to age, gender, presence of concomitant atopic diseases, eosinophil, and basophil counts/ percentages and serum total IgE levels (Table 1). However, the mean wheal size of SPT was greater in children with positive OFC (4 mm [IQR: 0-6]) than negative ones $(2 \mathrm{~mm}$ [IQR: 0-5]), likewise the median of the serum specific IgE (1.95 kU/l [0.7-5.71]) vs (1.06 kU/l [0.27-3.16]), respectively ( $\mathrm{p}<0.001)$. In addition, characteristics of OFC predictors were explored for in order to determine their impact on reactivity. The results revealed that OFC with sesame seeds (OR: 7.747 [Cl: 4.03-14.90]), wheat (3.80 [1.64-8.84]), tree nuts $(2.78$ [1.83-4.23]), age (1.070 [1.006-1.137]), and previous year's OFCs (1.29 [1.004-1.653]) predicted a positive OFC. Remarkably, the presence of multiple sensitization $(0.49$ [0.33-0.72]) was found to decrease the likelihood of positive OFC (Table 3a).

Compared with cow's milk (10/433) $(2.3 \%)$ or hen's egg $(6 / 388)(1.5 \%)$, significantly more OFC with tree nuts $(21 / 273)$ (7.6\%) and seeds (8/67) $(11.9 \%)$ rather met the criteria for anaphylaxis $(p<0.001)$. Furthermore, results from multivariate analysis revealed that concomitant asthma (3.61 [1.2710.28]) and previous year's OFCs (2.378 [1.362-4.154]) were more likely to elicit anaphylaxis $(p<0.05)$ (Table $3 b)$. 
Table 2 The food specific OFCs according age groups and positive outcomes.

\begin{tabular}{|c|c|c|c|c|}
\hline & Whole group $\mathrm{N}=1361$ & (+) OFC N = $131(9.6 \%)$ & $\leq 2$ years OFCs $(n=683)$ & $2-18$ years OFCs $(n=678)$ \\
\hline Cows' milk & 433 & $29(22.1)$ & $213(31.1)$ & $220(32.4)$ \\
\hline - Baked milk & 82 & $4(13.7)$ & $45(21.1)$ & $37(16.8)$ \\
\hline - Fermented milk & 233 & $13(44.8)$ & $102(47.8)$ & $131(59.5)$ \\
\hline - Raw milk & 118 & $12(41.3)$ & $66(30.9)$ & $52(23.6)$ \\
\hline Hens' egg & 388 & $19(14.5)$ & $212(31)$ & $176(26)$ \\
\hline - Baked egg & 41 & $3(15.7)$ & $4(1.8)$ & $37(21)$ \\
\hline - Egg white & 168 & $9(47.3)$ & $96(45.2)$ & 72 (40.9) \\
\hline • Egg yolk & 179 & $7(36.8)$ & $112(52.8)$ & $67(38)$ \\
\hline Tree nuts & 273 & $44(33.5)$ & $121(17.7)$ & $152(22.4)$ \\
\hline - Walnut & 67 & $16(36.3)$ & $28(23.1)$ & $39(25.6)$ \\
\hline - Almond & 64 & $4(9)$ & $33(27.2)$ & $31(20.3)$ \\
\hline - Pistachio & 55 & $5(11.3)$ & $13(10.7)$ & $42(27.6)$ \\
\hline - Hazelnut & 45 & $8(18.1)$ & $19(15.7)$ & $26(17.1)$ \\
\hline - Cashews & 42 & $11(25)$ & $28(23.1)$ & $14(9.2)$ \\
\hline Legume & 99 & $8(6.1)$ & $52(7.6)$ & $47(6.9)$ \\
\hline - Peanut & 40 & $2(25)$ & $22(42.3)$ & $18(38.2)$ \\
\hline - Lentil & 32 & $1(12.5)$ & $21(40.3)$ & $11(23.4)$ \\
\hline - Chickpea & 11 & $2(25)$ & $3(5.7)$ & $8(17)$ \\
\hline - Bean & 9 & $2(25)$ & $4(7.6)$ & $5(10.6)$ \\
\hline - Pea & 7 & $1(12.5)$ & $2(3.8)$ & $5(10.6)$ \\
\hline Seeds & 67 & $22(16.7)$ & $40(5.8)$ & $27(3.9)$ \\
\hline - Sesame & 51 & $18(81.8)$ & $29(72.5)$ & $22(81.4)$ \\
\hline - Poppy seeds & 12 & $4(18.1)$ & $9(22.5)$ & $3(11.1)$ \\
\hline - Sunflower seeds & 2 & 0 & $2(5)$ & 0 \\
\hline - Pumpkin seeds & 2 & 0 & 0 & $2(7.4)$ \\
\hline Wheat & 37 & $8(6.1)$ & $18(2.6)$ & $19(2.8)$ \\
\hline Red meat & 20 & $0(0)$ & $10(1.4)$ & $10(1.4)$ \\
\hline Fish & 14 & $1(0.7)$ & $3(0.4)$ & $11(1.6)$ \\
\hline Others & 30 & 0 & $14(2)$ & $16(2.3)$ \\
\hline
\end{tabular}

In positive OFCs, symptoms usually started after final dose $(25.8 \%)$ and less at the initial dose $(6.7 \%)$.

\section{Time trend}

The annual numbers of OFCs were 340 in 2017, 501 in 2018, and 520 in 2019. There was a trend of increase in the numbers over the years $(p=0.001)$. The proportion of children with an age of $\leq 2$ years were $46.8 \%, 57.7 \%$, and $45.2 \%$ in 2017, 2018, and 2019, respectively (Figure 2). Most of the OFCs with seeds (65.6\%) and tree nuts (50.9\%) were done in 2019 (Figure 3). There was a trend of increase in the number of OFCs over the years for tree nuts, seeds, and wheat ( $p<0.001)$. Positivity rate of OFCs by years were $6.8 \%$ for 2017, 8\% for 2018, and 13.1\% for 2019 ( $p=$ $0.003)$. Anaphylaxis occurred in $2 \%$ in $2017,1.3 \%$ in 2018 , and $6.9 \%$ in 2019 . There were no hospitalizations during the years 2017 and 2018. However, four hospitalizations (four patients) took place in 2019.

\section{Discussion}

OFC remains an essential diagnostic tool for pediatric allergy clinics. ${ }^{6}$ We have documented that cow's milk, hen's egg, tree nuts, and seeds are the most frequently considered OFCs. Most of the children evaluated were young ( $\leq 2$ years) and had more than one OFC. Over the years, there has been an increasing trend in the number of OFCs, especially the ones with tree nuts and sesame seeds. Along with these increases, the ratio of positive OFCs and hospitalizations also increased. Although reactivity can occur in any OFC, tree nut, wheat, and sesame seeds OFCs are more likely to have a positive OFC.

Our results showed that OFC has become a routine practice of an allergy clinic in the Eastern Mediterranean region. The upward trend in numbers and positive OFC ratios reflect increased experience, increased confidence, and risk-taking behavior. OFCs are time consuming and labor intensive procedures and carry risks of serious reaction. However, OFC is the gold standard, particularly when it comes to eliminating the risk of unnecessary food avoidance. ${ }^{12,16}$ Our OFC numbers are either slightly high ${ }^{17,18}$ or slightly low ${ }^{19,20}$ compared with previous studies. The numbers of OFCs are closely related to infrastructure and experience. However, we do not know how long the trend of increase in the numbers will last, but we anticipate that this increase will somehow be offset by increases in the positive OFC rates and the frequency of severe outcomes.

In Turkey, foods such as cow's milk, hen's egg, and wheat are less costly, readily available and the main sources of nutrition. Furthermore, cow's milk and hen's egg are the two most common causes of FA in our region ${ }^{3}$ as well as in 
Table 3 Predictors in univariate and multivariate analysis for (a) reactivity and (b) anaphylaxis.

\begin{tabular}{|c|c|c|c|c|c|c|}
\hline & \multicolumn{3}{|c|}{ Univariate } & \multicolumn{3}{|c|}{ Multivariate } \\
\hline & OR & $95 \% \mathrm{Cl}$ & $P$ & OR & $95 \% \mathrm{Cl}$ & $\mathrm{P}$ \\
\hline \multicolumn{7}{|l|}{ a) } \\
\hline Age & 1.063 & $1.002-1.127$ & 0.042 & 1.070 & $1.006-1.137$ & 0.030 \\
\hline Male-female & 0.751 & $0.504-1.118$ & 0.159 & & & \\
\hline Single-multıple food allergy & 0.498 & $0.344-0.721$ & 0.000 & 0.492 & $0.335-0.722$ & 0.000 \\
\hline Cows' milk & 0.581 & $0.378-0.893$ & 0.013 & & & \\
\hline Hens’ egg & 0.396 & $0.240-0.654$ & 0.000 & & & \\
\hline Sesame & 5.778 & $3.153-10.590$ & 0.000 & 7.747 & $4.027-14.903$ & 0.000 \\
\hline Tree nuts & 2.211 & $1.497-3.265$ & 0.000 & 2.779 & $1.827-4.225$ & 0.000 \\
\hline Wheat & 2.694 & $1.205-6.021$ & 0.016 & 3.804 & $1.637-8.839$ & 0.002 \\
\hline OFC for years & 1.491 & $1.169-1.902$ & 0.001 & 1.288 & $1.004-1.653$ & 0.046 \\
\hline \multicolumn{7}{|l|}{ b) } \\
\hline Age & 1.055 & $0.947-1.175$ & 0.331 & & & \\
\hline Single-multıple food allergy & 1.305 & $0.635-2.681$ & 0.468 & & & \\
\hline Asthma & 2.526 & $0.978-6.529$ & 0.056 & 3.615 & $1.271-10.280$ & 0.016 \\
\hline Tree nuts & 1.826 & $0.871-3.830$ & 0.111 & & & \\
\hline Total IgE & 1.000 & $1.000-1.001$ & 0.191 & & & \\
\hline OFC for years & 2.069 & $1.227-3.488$ & 0.006 & 2.378 & $1.362-4.154$ & 0.002 \\
\hline
\end{tabular}

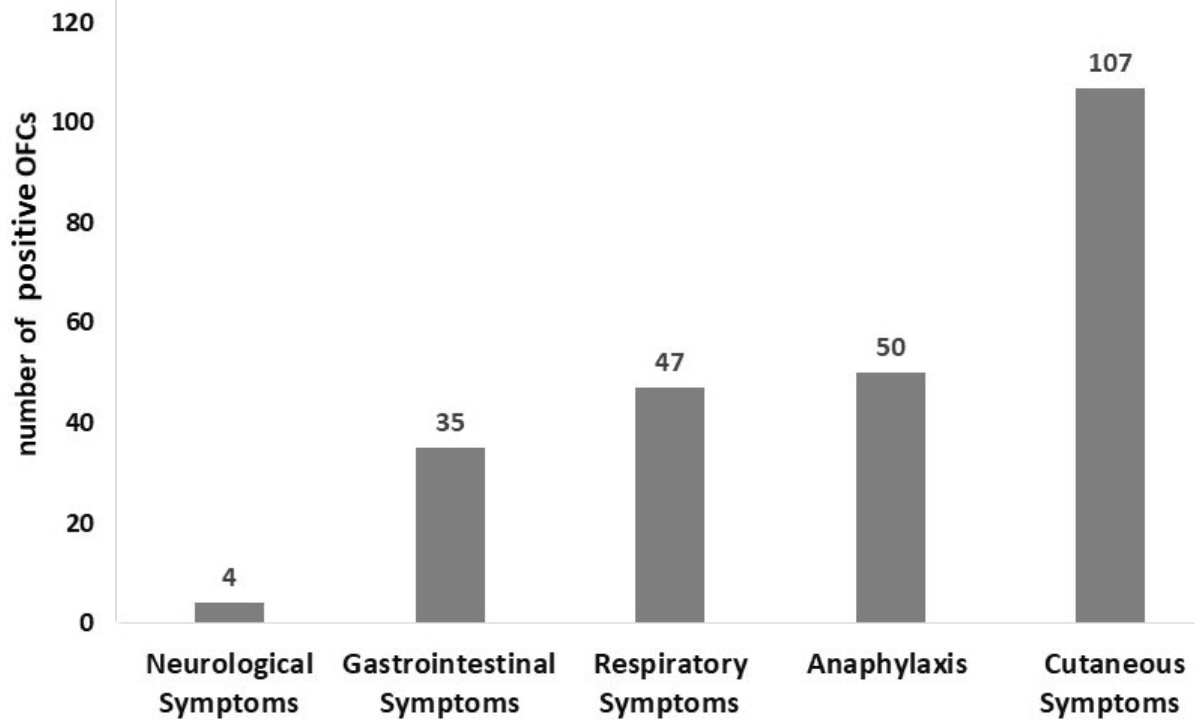

Figure 1 Symptoms during positive oral food challenge.

others. ${ }^{19}$ Therefore, it is an expected finding of this study that these food groups (i.e., cow's milk and hen's egg) will emerge as the most frequently utilized foods in OFCs. Cow's milk and hen's egg are common food products regardless of cultures. Hence in previous studies, most frequently evaluated foods with OFC were cow's milk and hen's egg. ${ }^{21,22}$

The prevalence of IgE-mediated food sensitization/ allergy is higher in the first 2 years of life ${ }^{23,24}$ and some of these can be tolerated or become tolerated within few years. ${ }^{25-27}$ This explains why our study population is young (median age 2 years) and why almost half of OFCs are performed at the age of 2 years or below. It is well known during the first 2 years of life that allergy testing identifies sensitivity in many, but most of them are actually tolerable. ${ }^{28,29}$ OFC can document most of the tolerable sensitivities. Not surprisingly, in developing countries such as Turkey, FA diagnosis is more frequently used along with increase in awareness. Therefore, OFCs seem to be a vital tool to overcome over-diagnosis. Similar to our study, the most frequently tested age group in previous studies evaluating OFC results was young children ( $<2$ years). ${ }^{30,31}$

Having allergies for more than one food group is a critical problem because constraints in daily life can lead to many consequences in nutrition, growth, and mental health. In such patients, OFC is vital both for eliminating unnecessary restrictions and for providing an effective 


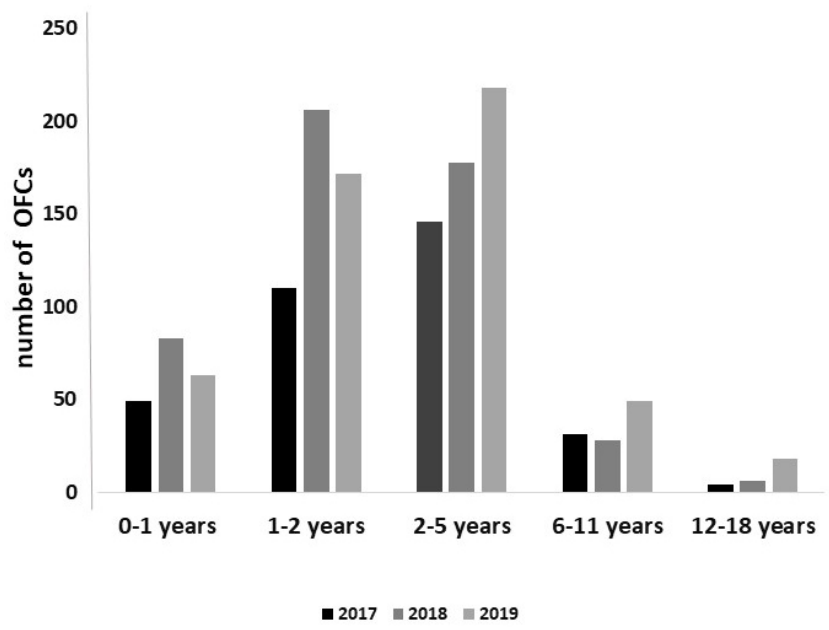

Figure 2 Distribution of oral food challenges (OFCs) according to age groups.

variety of diet. ${ }^{32,33} 57.2 \%$ of the patients included in this study had more than one FA/sensitization and therefore almost $55 \%$ of the study population required more than one OFC. Indeed, from the multivariate analysis, multiple food sensitization was observed to predict a lower likelihood of a positive OFC. We believe this indicates that a significant part of OFCs were performed to avoid the unnecessary elimination diets in multiple-sensitized individuals. In addition, with the increasing age, the likelihood of positive OFC increased, which supports the view that most of the OFCs in early years are indeed performed to either eliminate unnecessary diets or the expected reduction in the likelihood of tolerance development with increasing age. In the previous case series reviewing OFC results, multiple FAs ranged from 40 to $80 \% .18,34$

In our study, oral challenge failure rate was $9.6 \%$ whereas there was an allergic outcome in $33 \%$ and $29 \%$ in two previous studies. ${ }^{18,35}$ In our clinic, to be on the safer side, a ladder approach is preferred in milk and egg OFCs (baked, fermented). This is a potential cause of our low allergic reaction rates while creating a safer test environment. Thus; the positive rates, ranging from $16 \%$ to $32 \%$ observed in tree nuts, wheat, and sesame OFCs, support that our low positive rate in the whole group comes from a high number of milk and egg OFCs with individual positivity ratios of $6.7 \%$ and $4.9 \%$, respectively.

Peanut and seafood allergies are common in Englishspeaking Western countries, while tree nuts and sesame allergies are common in the Middle East and Eastern Mediterranean countries. ${ }^{3,36-38}$ Tree nuts and sesame consumption is quite high in Turkey and they are widely used in many recipes, including those for desserts and meats. Additionally, their consumption usually begins during infancy. This situation was reflected in our OFCs by the high number of OFCs with tree nut and sesame seeds. ${ }^{39}$

Prevention of severe reactions is essential to conduct safe OFC. As expected, in our study serum food specific IgE levels and mean wheal sizes of SPT were higher in failed OFCs. This is similar to previous studies ${ }^{17,40}$ which evaluated OFC outcomes. In multivariate analyses, OFC with sesame seeds, wheat, and tree nuts were found to predict a positive OFC which, together with food specific history and sensitivity measures, emphasize the need to assess food group specific risk factors as reported before. ${ }^{41,42}$ Furthermore, in multivariate analyses, the presence of asthma was found to be more likely to elicit anaphylaxis, as reported previously. ${ }^{43}$ Although the most important limitation of our study is the lack of predictive values for slgE and SPT of individual foods, its strength includes focusing on real-life OFC practice by including multiple OFCs over a 3-year period.

Definite diagnosis of allergies is very important in children who have or are thought to have FAs as unnecessary elimination diets may cause unnecessary anxiety as well as negative impact on nutrition. Though food challenges have inherent risks, studies show that parents experience reduced anxiety after a food challenge, even if the result is negative or positive. ${ }^{44-46}$

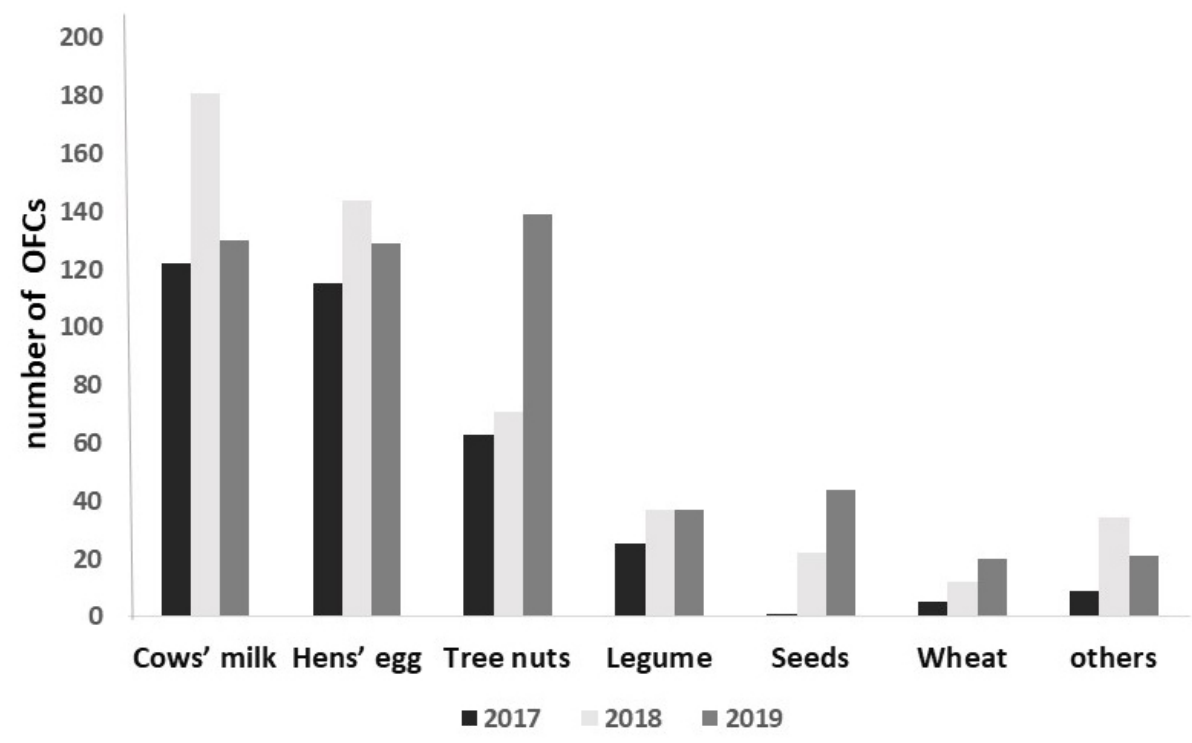

Figure 3 Food specific oral food challenges (OFCs) by years. 
In conclusion, we examined the rate, spectrum and predictors of OFC's reactivity in Eastern Mediterranean region based on our expectations that they will lead to safer, lower cost, less time, and labor-intensive processes. As expected, the results of the study showed that primary nutrition sources and the region's most specific common FAs were prioritized. Young children (i.e., preschool children) with multiple sensitivities/allergies were prioritized. Remarkably, some food groups (tree nuts, sesame, and wheat) predicted a reactive OFC and the presence of asthma in the development of anaphylaxis.

\section{Authors' Contributions}

Hilal Ünsal collected data and participated in review of files, data generation, entry and analysis and prepared the manuscript. E-mail: drhilalunsal@gmail.com

Gokce Ozyilmaz Bozat collected data and participated in review of files, data generation, and entry. E-mail: gokce_ozyilmaz@hotmail.com

Melike Ocak collected data and participated in review of files, data generation, and entry. E-mail: drmelikeocak@gmail.com

Aysegul Akarsu collected data and participated in review of files, data generation, and entry. E-mail: aysegulhicdurmaz@gmail.com

Umit Murat Sahiner contributed to patient screening, data analysis, and preparation of the manuscript. E-mail: umsahner@yahoo.com

Ozge Soyer contributed to patient screening, data analysis, and preparation of the manuscript. E-mail: ozgeusoyer@gmail.com

Bulent Enis Sekerel developed the design of the study, contributed collection of data and evaluation of results and wrote the manuscript with HÜ. E-mail: b_sekerel@yahoo.com

\section{Conflicts of Interest}

Authors declare that there is no conflict of interest and there was no funding provided.

\section{References}

1. Savage J, Johns CB. Food allergy: Epidemiology and natural history. Immunol Allergy Clin. 2015;35:45-59. https://doi. org/10.1016/j.iac.2014.09.004

2. Gupta RS, Springston EE, Warrier MR, Smith B, Kumar R, Pongracic $J$, et al. The prevalence, severity, and distribution of childhood food allergy in the United States. Pediatrics. 2011;128:e9-e17. https://doi.org/10.1542/peds.2011-0204

3. Kahveci M, Koken G, Şahiner ÜM, Soyer Ö, Şekerel BE. Immunoglobulin e-mediated food allergies differ in east Mediterranean children aged 0-2 years. Int Arch Allergy Immunol. 2020;181:365-74. https://doi.org/10.1159/000505996
4. Greiwe J. Oral food challenges in infants and toddlers. Immunol Allergy Clin. 2019;39:481-93. https://doi.org/10.1016/ j.iac.2019.07.003

5. Sicherer SH, Sampson HA. Food allergy. J Allergy Clin Immunol. 2010;125:S116-25. https://doi.org/10.1016/j.jaci.2009.08.028

6. Cox AL, Nowak-Wegrzyn A. Innovation in food challenge tests for food allergy. Curr Allergy Asthma Rep. 2018;18:74. https:// doi.org/10.1007/s11882-018-0825-3

7. Sicherer SH, Sampson HA. Food allergy: A review and update on epidemiology, pathogenesis, diagnosis, prevention, and management. J Allergy Clin Immunol. 2018;141:41-58. https:// doi.org/10.1016/j.jaci.2017.11.003

8. Niggemann B, Rolinck-Werninghaus C, Mehl A, Binder C, Ziegert M, Beyer K. Controlled oral food challenges in childrenwhen indicated, when superfluous? Allergy. 2005;60:865-70. https://doi.org/10.1111/j.1398-9995.2005.00828.x

9. Sampson HA, Ho DG. Relationship between food-specific IgE concentrations and the risk of positive food challenges in children and adolescents. J Allergy Clin Immunol. 1997;100:44451. https://doi.org/10.1016/S0091-6749(97)70133-7

10. Mankad VS, Williams LW, Lee LA, LaBelle GS, Anstrom KJ, Burks AW. Safety of open food challenges in the office setting. Ann Allergy Asthma Immunol. 2008;100:469-74. https://doi. org/10.1016/S1081-1206(10)60473-5

11. Noone S, Ross J, Sampson HA, Wang J. Epinephrine use in positive oral food challenges performed as a screening test for food allergy therapy trials. J Allergy Clin Immunol In Pract. 2015;3:424-8. https://doi.org/10.1016/j.jaip.2014.10.008

12. Sampson HA, Van Wijk RG, Bindslev-Jensen C, Sicherer S, Teuber SS, Burks AW, et al. Standardizing double-blind, placebo-controlled oral food challenges: American Academy of Allergy, Asthma \& Immunology-European Academy of Allergy and Clinical Immunology PRACTALL consensus report. J Allergy Clin Immunol. 2012;130:1260-74. https://doi. org/10.1016/j.jaci.2012.10.017

13. Niggemann B. When is an oral food challenge positive? Allergy. 2010;65:2-6. https://doi.org/10.1111/j.1398-9995.2009.02170.x

14. Perry TT, Matsui EC, Conover-Walker MK, Wood RA. Risk of oral food challenges. J Allergy Clin Immunol. 2004;114:1164-8. https://doi.org/10.1016/j.jaci.2004.07.063

15. Bindslev-Jensen C, Ballmer-Weber B, Bengtsson U, Blanco C, Ebner C, Hourihane J, et al. Standardization of food challenges in patients with immediate reactions to foodsposition paper from the European Academy of Allergology and Clinical Immunology. Allergy. 2004;59:690-7. https://doi. org/10.1111/j.1398-9995.2004.00466.x

16. Fleischer DM, Bock SA, Spears GC, Wilson CG, Miyazawa NK, Gleason MC, et al. Oral food challenges in children with a diagnosis of food allergy. J Pediatr. 2011;158:578-83. e571. https://doi.org/10.1016/j.jpeds.2010.09.027

17. Cianferoni A, Garrett JP, Naimi DR, Khullar K, Spergel JM. Predictive values for food challenge-induced severe reactions: Development of a simple food challenge score. Sat. 2012;11:20.

18. Abrams $E M$, Becker $A B$. Oral food challenge outcomes in a pediatric tertiary care center. Allergy Asthma Clin Immunol. 2017;13:43. https://doi.org/10.1186/s13223-017-0215-8

19. Itazawa $\mathrm{T}$, Adachi $\mathrm{Y}$, Takahashi $\mathrm{Y}$, Miura $\mathrm{K}$, Uehara $\mathrm{Y}$, Kameda $M$, et al. The severity of reaction after food challenges depends on the indication: A prospective multicenter study. Pediatr Allergy Immunol. 2020;31:167-74. https://doi. org/10.1111/pai.13140

20. Rolinck-Werninghaus C, Niggemann B, Grabenhenrich L, Wahn U, Beyer K. Outcome of oral food challenges in children in relation to symptom-eliciting allergen dose and allergenspecific I g E. Allergy. 2012;67:951-7. https://doi.org/10.1111/ j.1398-9995.2012.02838.x 
21. Sporik R, Hill D, Hosking C. Specificity of allergen skin testing in predicting positive open food challenges to milk, egg and peanut in children. Clin Exp Allergy. 2000;30:1541-6. https:// doi.org/10.1046/j.1365-2222.2000.00928.x

22. Niggemann B, Sielaff B, Beyer K, Binder C, Wahn U. Outcome of double-blind, placebo-controlled food challenge tests in 107 children with atopic dermatitis. Clin Exp Allergy. 1999;29:916. https://doi.org/10.1046/j.1365-2222.1999.00454.x

23. Du Toit G, Santos A, Roberts G, Fox A, Smith P, Lack G. The diagnosis of IgE-mediated food allergy in childhood. Pediatr Allergy Immunol. 2009;20:309-19. https://doi.org/ 10.1111/j.1399-3038.2009.00887.x

24. Sampson HA. Food allergy. Part 2: Diagnosis and management. J Allergy Clin Immunol. 1999;103:981-9. https://doi. org/10.1016/S0091-6749(99)70167-3

25. Wood RA, Sicherer SH, Vickery BP, Jones SM, Liu AH, Fleischer DM, et al. The natural history of milk allergy in an observational cohort. J Allergy Clin Immunol. 2013;131:80512. e804. https://doi.org/10.1016/j.jaci.2012.10.060

26. Sicherer SH, Wood RA, Vickery BP, Jones SM, Liu AH, Fleischer DM, et al. The natural history of egg allergy in an observational cohort. Journal of allergy and clinical immunology. 2014;133:492-9. e498. https://doi.org/10.1016/j.jaci.2013. 12.1041

27. Peters RL, Allen KJ, Dharmage SC, Koplin JJ, Dang T, Tilbrook KP, et al. Natural history of peanut allergy and predictors of resolution in the first 4 years of life: A population-based assessment. J Allergy Clin Immunol. 2015;135:1257-66. e1252. https://doi.org/10.1016/j.jaci.2014.12.1902

28. Verstege A, Mehl A, Rolinck-Werninghaus C, Staden U, Nocon M, Beyer $\mathrm{K}$, et al. The predictive value of the skin prick test weal size for the outcome of oral food challenges. Clin Exp Allergy. 2005;35:1220-6. https://doi.org/10.1111/j. 1365-2222.2005.2324.x

29. Eigenmann PA, Sampson HA. Interpreting skin prick tests in the evaluation of food allergy in children. Pediatr Allergy Immunol. 1998;9:186-91. https://doi.org/10.1111/j.1399-3038.1998.tb00371.x

30. Osborne NJ, Koplin JJ, Martin PE, Gurrin LC, Lowe AJ, Matheson MC, et al. Prevalence of challenge-proven IgEmediated food allergy using population-based sampling and predetermined challenge criteria in infants. J Allergy Clin Immunol. 2011;127:668-76. e662. https://doi.org/10.1016/j. jaci.2011.01.039

31. Isolauri E, Turjanmaa K. Combined skin prick and patch testing enhances identification of food allergy in infants with atopic dermatitis. J Allergy Clin Immunol. 1996;97:9-15. https://doi. org/10.1016/S0091-6749(96)70277-4

32. Nowak-Węgrzyn A, Assa'ad AH, Bahna SL, Bock SA, Sicherer SH, Teuber SS. Work Group report: Oral food challenge testing. J Allergy Clin Immunol. 2009;123:S365-83. https://doi.org/10.1016/j.jaci.2009.03.042

33. Niggemann B, Beyer K. Pitfalls in double-blind, placebocontrolled oral food challenges. Allergy. 2007;62:729-32. https://doi.org/10.1111/j.1398-9995.2007.01396.x

34. Perry TT, Matsui EC, Conover-Walker MK, Wood RA. The relationship of allergen-specific IgE levels and oral food challenge outcome. J Allergy Clin Immunol. 2004;114:144-9. https://doi. org/10.1016/j.jaci.2004.04.009

35. Dang AT, Chundi PK, Mousa NA, Beyer Al, Chansakulporn S, Venter $C$, et al. The effect of age, sex, race/ethnicity, health insurance, and food specific serum immunoglobulin $E$ on outcomes of oral food challenges. World Allergy Organ J. 2020;13:100100. https://doi.org/10.1016/j.waojou.2020.100100

36. Hossny E, Ebisawa M, El-Gamal Y, Arasi S, Dahdah L, Owaidy RE, et al. Challenges of managing food allergy in the developing world. World Allergy Organ J. 2019;12:100089. https://doi.org/10.1016/j.waojou.2019.100089

37. Woods RK, Thien F, Raven J, Walters EH, Abramson M. Prevalence of food allergies in young adults and their relationship to asthma, nasal allergies, and eczema. Ann Allergy Asthma Immunol. 2002;88:183-9. https://doi.org/10.1016/S1081-1206(10)61994-1

38. Lee AJ, Thalayasingam M, Lee BW. Food allergy in Asia: How does it compare? Asia Pac Allergy. 2013;3:3-14. https://doi. org/10.5415/apallergy.2013.3.1.3

39. Cetinkaya PG, Buyuktiryaki B, Soyer O, Sahiner UM, Sackesen C, Sekerel BE. Phenotypical characterization of tree nuts and peanut allergies in east Mediterranean children. Allergol Immunopathol. 2020;48:316-22. https://doi.org/10.1016/j.aller.2019.07.005

40. Celik-Bilgili S, Mehl A, Verstege A, Staden U, Nocon M, Beyer $\mathrm{K}$, et al. The predictive value of specific immunoglobulin $E$ levels in serum for the outcome of oral food challenges. Clin Exp Allergy. 2005;35:268-73. https://doi. org/10.1111/j.1365-2222.2005.02150.x

41. Muraro A, Werfel T, Hoffmann-Sommergruber K, Roberts G, Beyer $\mathrm{K}$, Bindslev-Jensen $\mathrm{C}$, et al. EAACl food allergy and anaphylaxis guidelines: Diagnosis and management of food allergy. Allergy. 2014;69:1008-25. https://doi.org/10.1111/ all.12429

42. Sindher S, Long AJ, Purington N, Chollet M, Slatkin S, Andorf S, et al. Analysis of a large standardized food challenge data set to determine predictors of positive outcome across multiple allergens. Front Immunol. 2018;9:2689. https://doi. org/10.3389/fimmu.2018.02689

43. Simberloff T, Parambi R, Bartnikas LM, Broyles AD, Hamel V, Timmons KG, et al. Implementation of a standardized clinical assessment and management plan (SCAMP) for food challenges. J Allergy Clin Immunol In Pract. 2017;5:335-344. e333.

44. Zijlstra WT, Flinterman AE, Soeters L, Knulst AC, Sinnema G, L'Hoir MP, et al. Parental anxiety before and after food challenges in children with suspected peanut and hazelnut allergy. Pediatr Allergy Immunol. 2010;21:e439-45. https:// doi.org/10.1111/j.1399-3038.2009.00929.x

45. Kemp AS, Allen CW, Campbell DE. Parental perceptions in egg allergy: Does egg challenge make a difference? Pediatr Allergy Immunol. 2009;20:648-53. https://doi. org/10.1111/j.1399-3038.2009.00859.x

46. DunnGalvin A, Cullinane C, Daly D, Flokstra-de Blok B, Dubois A, Hourihane JOB. Longitudinal validity and responsiveness of the Food Allergy Quality of Life QuestionnaireParent Form in children $0-12$ years following positive and negative food challenges. Clin Exp Allergy. 2010;40:476-85. https://doi.org/10.1111/j.1365-2222.2010.03454.x 